\title{
Developing a thermal design for steam power plants by using concentrating solar power technologies for a clean environment
}

\author{
Layth M. ABD ALI ${ }^{1 *}$, Qays A. ALI ${ }^{2}$, Ivana KLAČKOVÁ̈, Hayder A. ISSA ${ }^{4}$, \\ Boris A. YAKIMOVICH ${ }^{5}$ and Vladimir V. KUVSHIMOV ${ }^{5}$
}

\begin{abstract}
Authors' affiliations and addresses:
${ }^{1}$ University of Kufa, presidency University of Kufa

Najaf, 54001, Iraq

e-mail: laithm.abood@uokufa.edu.iq

${ }^{2}$ Northern Technical University, Kirkuk, 36001, Iraq

e-mail: qaysadnanali153@gmail.com

${ }^{3}$ University of Žilina, Faculty of Mechanical Engineering, Department of Automation and Production Systems, Univerzitná 8215/1, 01026

Žilina, Slovakia

e-mail: ivana.klackova@fstroj.uniza.sk

${ }^{4}$ University of Thi-Qar, Thi-Qar, 64001, Iraq e-mail: haeder.issa84@gmail.com

${ }^{5}$ Federal State-Funded Educational Institution of Higher Professional Education "Sevastopol State University", Institute of Nuclear Energy and Industry, Sevastopol, 299015, Russia

e-mail: kuvshinov.vladimir@gmail.com

*Correspondence:

Layth M. Abd Ali, University of Kufa, presidency University of Kufa Najaf, 54001, Iraq tel.: +79785868160

e-mail: laithm.abood@uokufa.edu.iq
\end{abstract}

Acknowledgement: The authors would like to thank the University of Kufa and the Institute of Nuclear Energy and Industry in Sevastopol State University for their continuous support.

This work was carried out with the financial support of an internal grant from the Federal State Autonomous Educational Institution of Higher Education "Sevastopol State University" No. 27 / 06-31

How to cite this article:

Layth M. Abd Ali, L M., Ali, Q. A., Klačková, I., Issa, H. A., Yakimovich, B. A. and Kuvshimov, V. (2021) Developing a thermal design for steam power plants by using concentrating solar power technologies for a clean environment. Acta Montanistica Slovaca, Volume 26 (4), 773-783

DOI:

https://doi.org/10.46544/AMS.v26i4.14

\begin{abstract}
A significant number of installations based on renewable energy sources are currently used in energy complexes in regions with high solar radiation. In particular, importance is attached to the use of direct solar energy conversion systems. The use of solar installations to provide thermal and electric energy is one of the promising areas of resources and energy saving. For more efficient use of solar energy, you can use combined plants that produce both thermal and electrical energy. Installations themselves to save materials, space and assembly time can be combined with the roof of buildings and structures. The authors of the presented work conducted experimental studies and obtained comparative characteristics of the operation of thermal, photovoltaic and combined solar installations. The main purpose of this study is to discuss the possibility of the development of thermal design power plants to produce electric power conventional steam to work the semi-joint system to exploit an array of solar collectors concentrated type parabolic cylindrical in processing the amount of thermal energy for steam turbine unit. In the study of the effectiveness of different designs to link Matrix complexes solar concentration in thermal design of the plant steam and as a measure of effectiveness was the use of the amount of savings in the amount of fuel consumed for the production of an electric power network, as a result of the use of matrix compounds concentrating solar power (CSP) study showed economic efficiency and environmental design of the proposed terms of the amount of savings the lowest in the amount of fuel consumed in the network 177.5 tons/year.

Design of thermal energy for solar collectors concentrated matrix. Accordingly, the decrease in the amount of thermal energy and the amount of nitrogen oxides, which produced in the surrounded medium 0.628 tons.
\end{abstract}

\section{Keywords}

developing steam power using (CSP) technologies, solar power, collector, power plants. 


\section{Introduction}

Electric power is one of the pillars upon which the modern Renaissance in various forms and the artery that feeds the various social and economic activities. In recent years, have been focused most scientific research in the field of energy on ways to rationalize the consumption of conventional energy sources and the preservation of the environment from pollution sources (Kuvshinov et al., 2019). As a result of this focus to develop means and methods for multiple uses of secondary sources of energy and new energy sources and renewable energy in the production of electric power (Akatov et al., 2019). The results of recent studies in the field of solar energy to the effective use of matrices complexes concentrated solar-type parabolic cylindrical in the production of electric power and thermal energy needed for some applications industrial (Kuznetsov et al., 2020). As well as the results of previous studies indicated the possibility of increasing the economic efficiency of solar power stations through the achievement of a common system for the operation of this type of station on solar radiation energy and traditional fuels (Ivanov, 2007). It is essential to have clean air when heat transfers to the collectors for successful results. (Cernecky et al., 2015).

Based on the foregoing, and keep pace with industrial progress and technological development in the area of production of electric power and fulfil the requirements of future consumption for the consumption of conventional energy sources and to maintain the lowest level of contamination of environment we will address in the current study to examine the effectiveness of the development of thermal design power plants to produce electric power conventional steam to work the system quasi-common by which trying to exploits the thermal energy matrix of the steam turbine unit (Abd Ali and Anssari, 2019). Of course, in this case, must take into account the impact of design features and specifications of the steam turbine unit, climatic conditions, and the nature of weather in the site being considered on the effectiveness of the proposed design of the station similarities shared solar (Alsharkawi and Rossiter, 2016).

\section{The basic design of the plant steam}

The basic design consists of a steam boiler plant with a production capacity ( 338.26 tons/hour) and a condensing steam turbine unit with one axis, and a design capacity of 120 megawatts. Steam turbine operating at elementary properties of steam $\left(T_{0}=535^{\circ} \mathrm{C}, P_{0}=128.47\right.$ bar $)$. One stage is to re-heat the steam in the boiler $(P R H=29.87)$ bar $\left(T R H=535^{\circ} \mathrm{C}\right)$, as shown in Figure 1 . The steam turbine consists of three cylinders (HPT, IPT, LPT).

Ready from the expansion of steam boiler $\left(T S B=540{ }^{\circ} \mathrm{C}, P S B=137.47\right.$ bar $)$ includes six points to drain the steam from the cylinder for the purpose of a retrospective of the heating feed water table (1) (Abdali \& Al-Rufaee, 2019).

Table 1. The properties of steam at various points of attrition of steam turbine.
\begin{tabular}{|c|c|c|c|c|c|c|c|}
\hline point & 1 & 2 & 3 & D & 4 & 5 & k \\
\hline p & 29.8 & 16.2 & 9.43 & 4.7 & 2.15 & 0.7 & 0.5 \\
\hline TC & 329 & 460 & 381 & 296 & 211 & 108 & 34 \\
\hline
\end{tabular}

\section{Designs of the studied Plant similarities shared solar}

The proposed design of the station similarities solar array that contains a matrix of concentrated solar collectors of both the concentration type solar parabolic cylindrical parts in addition to those mentioned above in the basic design of the steam plant (paragraph 2) (Sviatskii et al., 2020; Domnina and Pivarčiová, 2019). Where they are in accordance with the design of the proposed use of concentrated solar matrix complexes in the processing of the amount of thermal energy for steam turbine unit through the heating system for water retrospective feed water (Abd Ali et al., 2018). Which lead to a decline in the amount of steam from the turbine user for the purpose of heating water for retrospective compensation and then the low rate of fuel consumption in the boiler due to the fall amount of steam supplier of steam turbine unit (Vologdin et al., 2019). Where the modus operandi of the proposed design of the system is similar to the common characteristics and specifications of the design of the steam turbine unit. Therefore, the study includes the following methods to the functioning of the station in the semi-common (Kuvshinov et al., 2019).

\section{The first method}

In the case of a reserve to increase the rate of increase in the flow of steam in the final stages of the steam turbine and the amount of electrical power produced by the generator. In this way, the steam turbine unit works at the design flow rate to the amount of processed steam boiler $(D O=$ con) and within the steam turbine is the extending amount of steam for the process of non-extracted for the heating retrospective of feed water. Thereby increasing the flow rate of steam to the condenser $(D K=$ var.) and then increasing of electrical energy produced by the steam turbine ( $N E=$ var.) (Cheboxarov et al., 2019). 


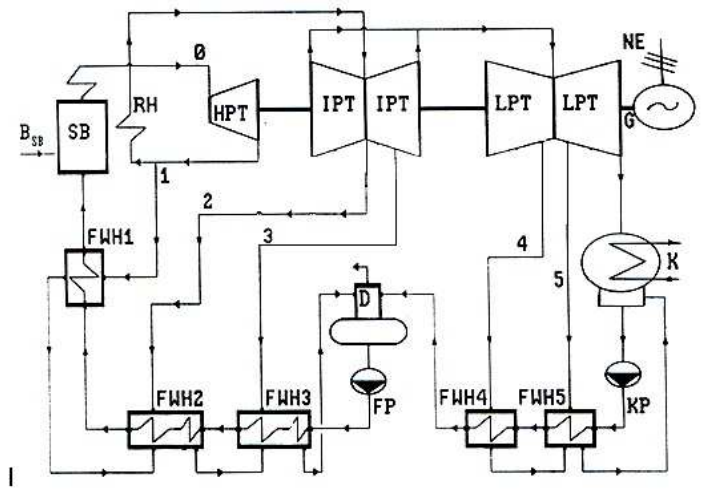

Fig 1. The basic design of the Steam Station.

\section{The second method}

In the absence of a reserve to increase the power of the generator. In this way is within the steam turbine extend the amount of steam for the process of an unextracted heating retrospective of the feed water ( $\mathrm{DK}=\mathrm{var}$.) in this case, the constant amount of Electric energy produced was maintained ( $\mathrm{NE}=\mathrm{con}$.). This leads to a lower rate of consumption of fuel in the boiler (Abd Ali et al., 2020).

\section{The third method}

In case of the absence of a reserve to increase the steam flow rate in the final stages of the steam turbine. In such a way as to reduce the amount of processed steam for steam turbine unit by the largest amount of non-steam extracted retrospective of the heating process of water nutrition (Blatnický et al., 2020). In order to maintain the rate design for the flow of steam in the last stage of the steam turbine ( $\mathrm{Dk}=\mathrm{con}$ ), which lead to a decline in the amount of electricity produced (NE = var.) of the turbine unit and decline the rate of consumption of fuel in the boiler. From the foregoing that the effectiveness of the proposed design of the plant similar to the common solar system will depend on how connecting solar concentrated matrix complexes in the thermal design of the steam plant (Figiel and Klačková, 2020). This is in addition to the technical limitations of the workstation in the solar system similar to the joint (Cheboxarov et al., 2019). To that end, in the current study, the following proposal is to link the design matrix complexes concentrated solar heating system in the retrospective of the feed water (Škare et al., 2020).

\section{First Studied Design}

This is according to the suggested design (Figure 2). Link matrix complexes solar concentrated with a tank of disarmament air and gases dissolved in the water feeding (D). Thus, in the case of solar radiation is processing the amount of thermal energy producing a matrix complexes Dream Castle solar heating system to the retrospective of feed water (Pástor et al., 2020; Pavlenko et al., 2020). This leads to a decline in the amount of steam turbine extracted from steam tanks to remove dissolved air and gases (Layth et al., 2019). then either increase the powerproducing steam turbine unit in the first case the way for the operation of the station. If the first method for the operation of the station in the system is similar to a joint or lower the amount of processed steam turbine unit in the case of the other methods of joint working station solar similarities and thus drop the amount of fuel consumed to produce electricity (Guryev et al., 2019). 


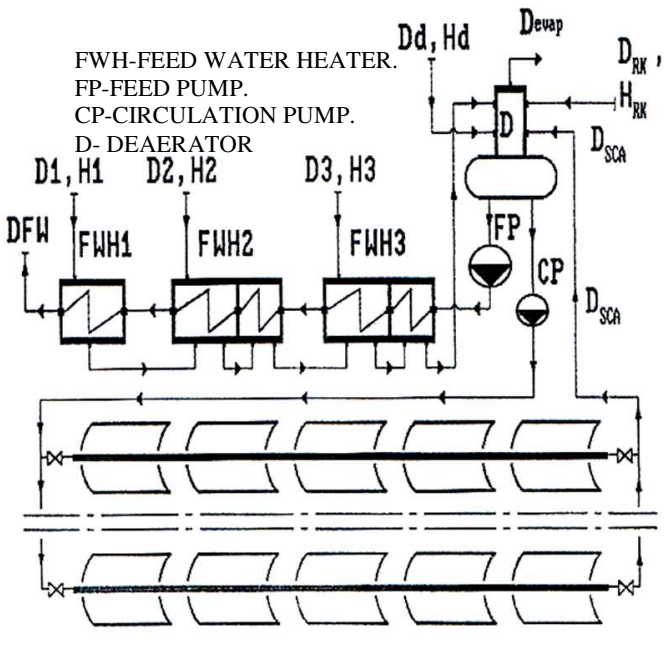

SOLAR COLLECTORS ARRAY

Fig.2. The design considered the first to link a solar matrix collector at the plant steam.

\section{The second studied design}

As is well known when using the process of re-heating steam in the thermal design of the steam plant to be the maximum temperature of the steam turbine extracted of steam for the purpose of heating water retrospective Nutrition is located at the point of attrition after re-heating operation directly (Abdali et al., 2020). So as to reduce the amount of loss in the steam extracted to the process of heating retrospective and increase the effectiveness of the proposed design of the station near the joint has been developed design considered the first (paragraph 3-1), where it was in accordance with the proposed design (Fig. 3) processing the amount of thermal energy produced for a matrix solar collectors for concentrated, heated gases II (FWH2), which lead to a decline in the amount of steam turbine extracted of steam heaters for a kinetic second, (FWH2) and third (FWH3) and tank removal of dissolved air and gases and this will depend on the amount of thermal energy to the design matrix Concentrated solar collectors on the amount of thermal energy needed for heating feedwater heater in the heat of this second addition to the technical parameters of the functioning of the proposed design of the system similar to a common (Almsater et al., 2016).

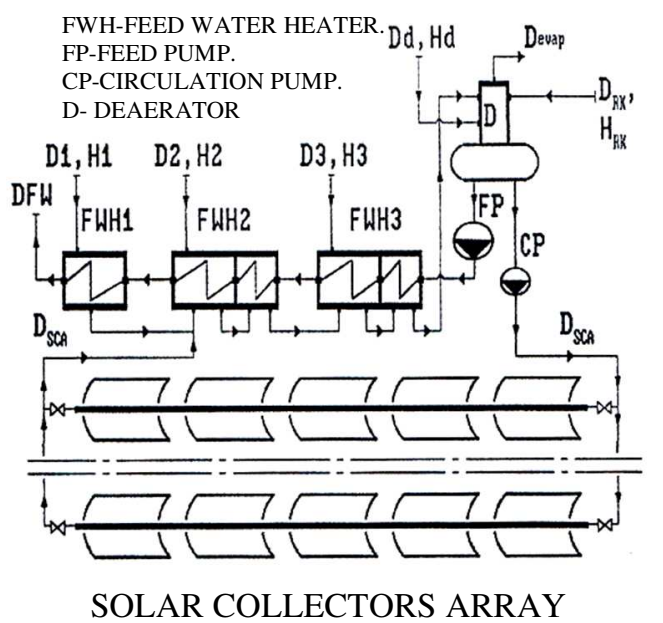

Fig. 3. The design considered the second to link the matrix compounds in the Solar Steam Plant.

\section{The third studied design}

Featuring some of the designs of conventional steam stations, the high number of heaters in the thermal heating system used in the retrospective of water nutrition, which lead to a decline in the amount of thermal energy needed to heat the feed water and condensate in the main heated gases (Abdali et al., 2020).

In order to increase the effectiveness of the proposed design of the station shared similarities in the case of falling solar thermal energy design of the heated gases and when there is a big reserve to increase the flow rate of steam in the final stages of the steam turbine has been considered second to modify the design (paragraph 2.3). Where they are in accordance with the proposed design (Fig. 4) processing the heat transfer fluid. After his release from 
matrix compounds concentrated solar to the tank remove the air and dissolved gases as well as to system heating retrospective of the feed water with high pressure, taking into account the amount of loss in the steam out of the system, which leads in the case of design lessons (Fig. 4) any decline in the amount of steam. Leech of steam turbine for heating the heated gases in retrospective II (FWH2) removal and tank air and gases dissolved (D) in addition to heated gases III (FWH3) and this will depend on the amount of thermal energy to the design matrix complexes the concentrated solar thermal energy needed to heat the heated gases in the retrospective and the second tank remove dissolved air and gases. matrix complexes in the plant steam (González-Roubaud et al., 2017).

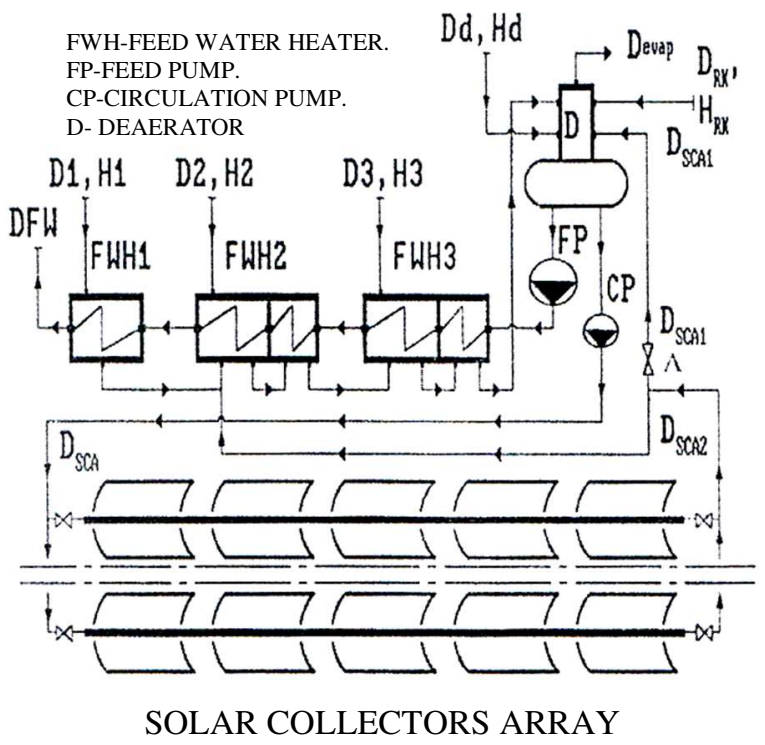

Fig 4. The design considered the third link solar matrix complexes in the plant steam.

\section{Material and Method of studying the effectiveness of the proposed designs}

To study the effectiveness of using solar concentrated matrix complexes of the type of parabolic cylindrical in thermal design of the conventional steam plants, it requires the expense of several different alternatives of the proposed design of the plant similar to the common solar features from each design change considered to link the matrix complexes concentrated in solar thermal design unity turbine steam and the way the leg work in the semijoint. In a measure of the effectiveness of economic and maintaining the lowest level of pollution of the central Pacific was to study the adoption of the amount of savings in the amount of fuel consumed for the production of electric power network as a result of the use of matrix compounds in solar thermal design of the plant steam so they can reflect the amount of savings in the amount of fuel consumed for the production of electric power the following relationship: (Janič et al., 2019; Rimar et al., 2020)

$$
D B S T=(B S B) 0+\frac{3600^{*}}{Q C V^{*}}-\begin{aligned}
& D N E \\
& B S B \\
& E S T
\end{aligned}=>\max
$$

\section{Where:}

$B S B(B S B)$ - Fuel consumption rate of the boiler in the basic design of the steam plant and the proposed design of the joint sub-station solar order (tonไhr)

$E S T$ - The efficiency of the plant for the production of countervailing power

$Q c v$ - Calorific value of fuel quality $(\mathrm{kJ} / \mathrm{kg})$

$D N E$ - Amount of change in the amount of electrical power produced by steam turbine unit as a result of the use of concentrated solar array complexes (MW) and is calculated from the following relationship:

$$
D N E=N E-(N E) 0=>
$$

$N E,(N E) 0$ - Electricity-producing steam turbine unit in the basic design of the plant steam and proposed design of the plant similar to the common solar order (MW).

Thus, the appropriate replacement is the one that gives the maximum value of the integration of equation (1) yearround (Repko et al., 2020). To undertake this study method was used mathematical modelling. Where was written 
algorithm, the mathematical model proposed for the station in accordance with the nature of the technical and physical designs studied and the way the work station in the system similar to the common solar, according to the methods adopted and used to conduct these types of accounts and method of calculating the thermal design of the steam stations.

- Clear sky method to estimate the amount of solar radiation on the surface of the land (Conrado et al., 2017).

- Method of calculating the thermal design and specifications for the design of solar collectors concentrated parabolic cylindrical. It should be noted that the study was to calculate the amount of solar radiation on the surface of the earth the adoption of the nature of weather and climatic conditions of the station site at the corner of latitude 37.78 degrees (Vins et al., 2020). In addition, the properties used in the approved design for concentrating solar collectors.

\section{Results of a study the effectiveness of the station similarities shared solar system}

The effectiveness of the proposed design for the station similarities common solar mainly on the properties and specifications design of the unit turbine steam. So it has been a study to examine the effect of method of operation of the proposed design of the system similar to a common solar (paragraph 3 ) on the amount of savings in the amount of fuel consumed by the relationship (1) and determining the effectiveness of designs studied to link the matrix complexes concentrated solar in the thermal design of the plant steam (Klačková et al., 2019). The results indicate that the proposed design of the station common solar design in the case considered the first high amount of savings in the amount of spent fuel (DBST) with more time virtual (LAT) in the morning (Fig. 5) to be up to the maximum value at midday $(L A T=12 \mathrm{~h})$ dropped by the virtual $\mathrm{g}$. The reason for this is to increase the amount of thermal energy-producing complexes concentrated solar array ( $Q S C)$ as a result of the high amount of solar radiation that falls on the surface of the matrix $(E T A)$.

Then decline in the amount of steam from the turbine steam extraction to remove the air tank and dissolved gases and therefore the high amount of the increase in the amount of electric power-producing steam turbine unit $(D N E)$ according to the method first proposed design for the operation of the system similar to common solar (Kuric, 2019). Then, as shown in Fig. (5) start value of the amount of savings in the amount of fuel consumed in the fall increase time with the virtual.

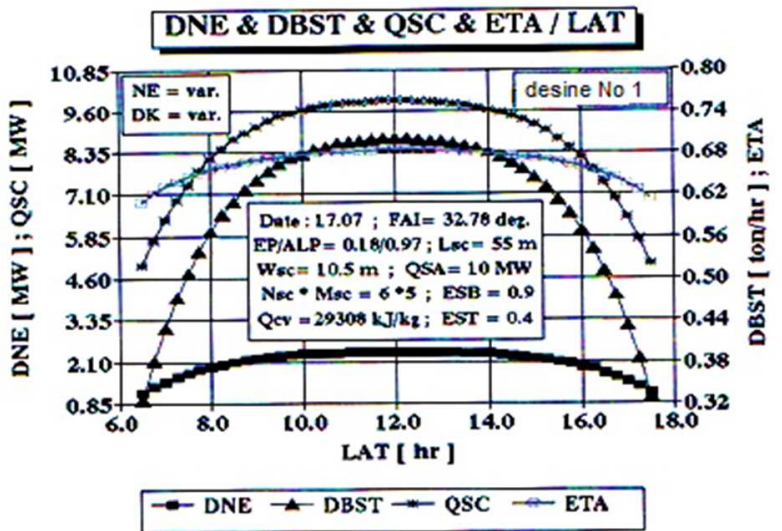

Fig.5. The relationship of the design specifications for the station-shared similarities with the solar time in the case of virtual design and the way I studied first for the operation of the station.

Because of the decline in the amount of direct solar radiation that falls on the surface of a matrix complex, concentrated solar and low efficiency of this matrix (Puškár et al., 2019). Leading to a decline in the amount of electricity-producing steam turbine unit as a result of low thermal energy produced for solar matrix collectors. It is noted from Fig. (5) increase the efficiency of solar matrix collectors in the morning (LAT<12 h) for the operation of solar matrix collectors and a decrease in the evening ( $L A T>12 \mathrm{~h}$ ). The reason for this could be interpreted to increase the amount of solar radiation absorbed and the high temperature of the surrounding medium in the morning. Then increase the amount of thermal energy produced for solar matrix collectors by the biggest rise in the amount of heat loss to the middle of the ocean (Kuric, I., Císar, M. et al., 2017). Either in the evening, the amount of decrease in the amount of thermal energy produced for the matrix solar collector is greater than the decline in the amount of heat loss to the middle of the ocean has been studying the impact of the second design considered (paragraph 2.3) and third (paragraph 3.3) on the effectiveness of the proposed design of the plant similar to the common solar system. As seen from Fig. (6) the high amount of savings in the amount of fuel consumed $(D B S T)$ and the amount of the increase in the amount of electricity produced (DNE) compared with the design considered the first (Fig. 5) due to the increase in the amount of thermal energy to the design matrix solar collectors $(Q S A 3=21 \mathrm{MW}), Q S A 2=14 \mathrm{MW})$. The decline in the amount of loss extracted steam for heating water revisionist nutrition, particularly in the second heat of the heated feed water and then rise in the amount of work done by steam (an extracted retrospective of the heating process) within the steam turbine. As well as shown in Fig. (6) the 
high effectiveness of the proposed design of the station shared similarities with the increase in the amount of solar thermal energy design matrix complexes concentrated solar.

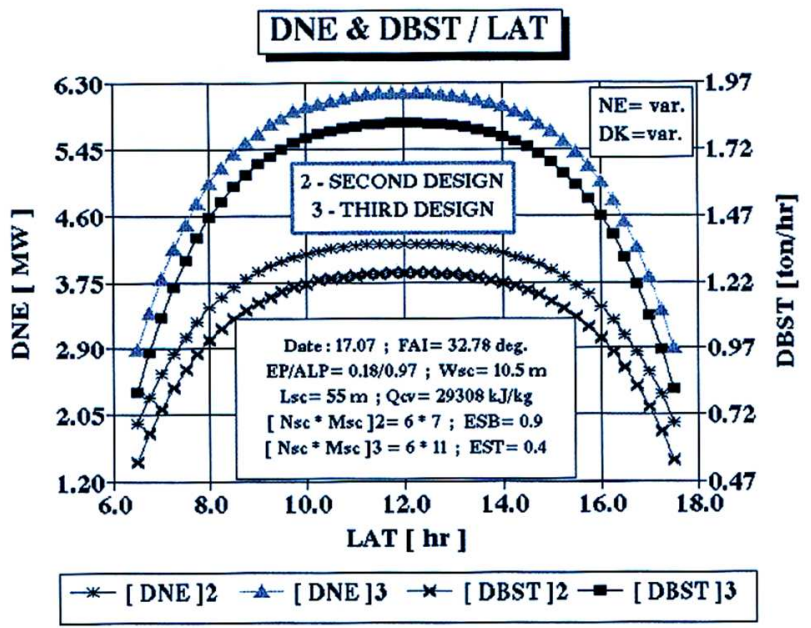

Fig. 6. The relationship of the design specifications for the station shared similarities with the solar time in the case of virtual designs studied the second, third and first method of operation of the station.

So studied the effect of using the second method for the operation of the proposed design of the station similarities shared solar on the amount of savings in the amount of fuel consumed (DBST). Where we note from Fig. (7) as compared to (6) that there are closely related to the amount of savings in the amount of fuel consumed with the virtual time. But in this case, an increase in the amount of thermal energy-producing compounds concentrated matrix leads to a high amount of the increased rate of flow of steam in the final stage of the steam turbine $(D D K)$ (Dodok et al., 2017). The amount decline in the amount of processed steam for steam turbine unit $(D D O)$ and then the low rate of fuel consumption of the boiler as a result of the fall in the amount of steamproducing boiler in a solar system similar to the joint. As well as shown in Fig. (7), there is a slight decrease by savings in the amount of fuel consumed, compared with (Fig. 6).

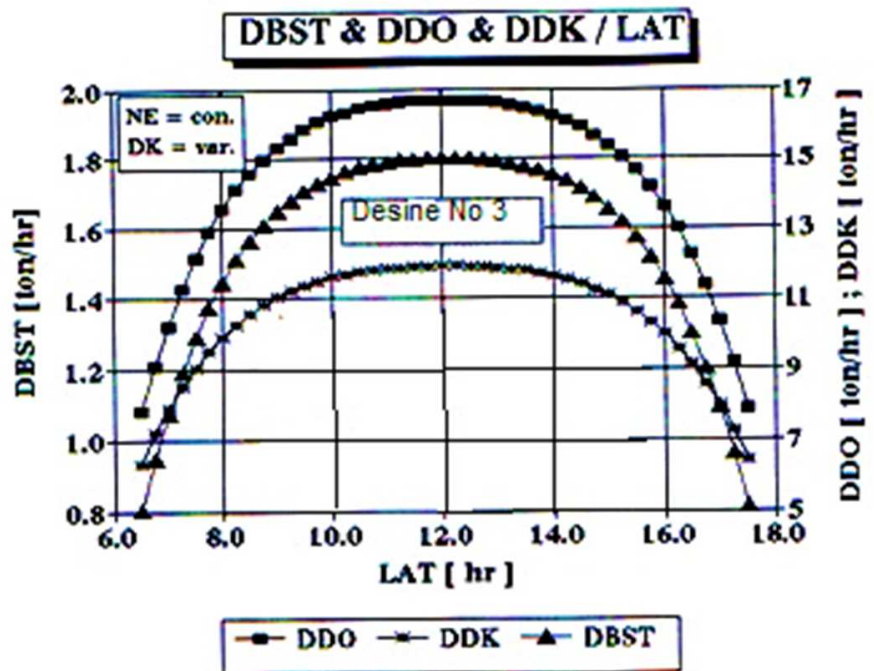

Fig. 7. The relationship of the design specifications for the station shared similarities with the solar time in the case of virtual design, considered the third and second method of operation of the station.

The reason for this is due to the slight difference between the efficiency of the station compensated to produce electric power and the efficiency of the basic design of the plant steam $((E S T) 0=0.395)$. It is noted from Fig. (7) that the amount of decline in the amount of steam supplier of steam turbine unit greater than the amount of the increase in the rate of flow of steam in the last stage of the steam turbine. Because of the high extracted steam to the heating process in retrospective heaters heat that affects them the amount of thermal energy-producing complexes concentrated solar array in accordance with the design considered the third has been studying the impact of the use of third way for the operation of the proposed design of the plant similar to common on the amount of solar saving the amount of fuel consumed during the month $(D B M)$ at different values of the efficiency of the plant for the production of countervailing power $(E S T)$. Where the notes of Figure (8) high amount of savings in the amount of fuel consumed during the month in the summer $(8,7,6,5$ months) compared with winter months $(2$, 
$1.12,11)$. The reason for this could be interpreted to increase the amount of direct solar radiation that falls on the surface of complexes concentrated solar array during summer compared with winter due to the nature of the control system used in the routing matrix complexes concentrated solar (radiation centre movement about one axis elongated horizontally from the north to the south). This, along with the sun, passes over the northern hemisphere during the summer and the weather at the site studied (the angle of latitude 37.78 degrees). Then the high amount of thermal energy vector of solar matrix collectors (Liaposhchenko et al., 2019). Thus, an increase in the amount of decline in the number of steam suppliers of steam turbine units, which leads to a high drop in electric powerproducing steam turbine units during the month $(D N M)$ and the rate of fuel consumption at the boiler (Kuric, I., Gorobchenko, O. et al., 2017). As well as the note of Fig. (8), a high amount of savings in the amount of fuel consumed during the month with compensatory increase the efficiency of the plant to produce electric power (Wiecek et al., 2019). Because of the low rate of fuel consumption to produce an electric power station is compensatory compared with the basic design of the station (Kuric et al., 2021). The integration was conducted throughout the year to the amount of savings in the amount of fuel consumed from the relationship (1) and all methods studied for the operation of the proposed design of the plant similar to the common solar at different values of the efficiency of the plant compensatory.

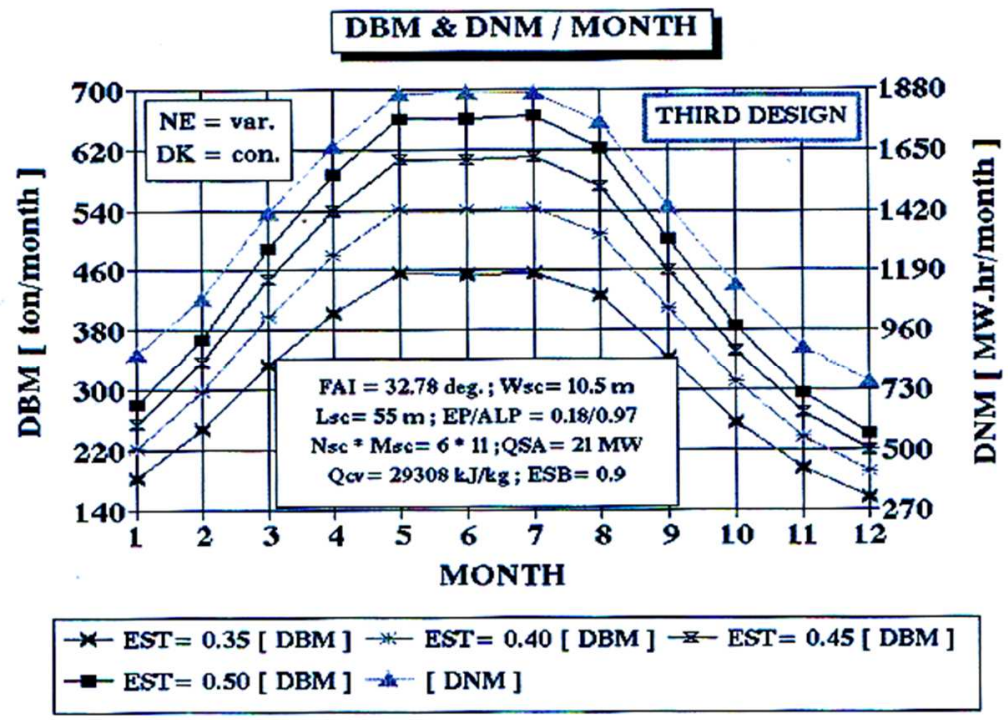

Fig. 8. Relationship with the amount of savings in the amount of fuel consumed (DBM) and the amount of the decline in electrical power produced (DNM) during the month of the station and solar similarities shared different month of the year in the case of the third way for the operation of the station.

\section{Discussion}

Regarding the steam turbine modelling tool developed in this work, although it is considered to have achieved an acceptable level in relation to the legitimate objectives, there is also room for enhancement, especially enhancement related to making it more user-oriented and more general in relation to the turbine models available in the industry. A new turbine for every time is developed inside the utility; the tool is enhanced with its new properties. From an academic point of view, there was no need to automate the instrument with respect to every new model of turbine for study.

\section{Conclusions}

Results of a study on the effectiveness of common solar plant similarities suggest:

1. Effectiveness of using concentrated solar array complexes of the type of parabolic cylindrical in processing the amount of thermal energy for steam turbine unit through the heating system retrospective of water nutrition. Where it reached the lowest savings in the amount of fuel consumed for the production of electrical energy (177.5 ton /year) per MW of thermal energy to the design matrix complexes concentrated solar, according to the amount of the decrease in thermal energy and the amount of nitrogen oxides in the environment surrounding (0.628 ton /year; 5204 GJ/year. MW).

2. Dependent effective solar station similarities are shared mainly on the properties and design specifications of the steam turbine unit.

3. Compensatory increase the efficiency of the plant to produce electric power by $25 \%$ on the efficiency of the basic design of the plant steam leads to the high amount of savings in the amount of fuel consumed 
during the year by $22 \%$ in the case of maintaining a fixed rate for the flow of steam in the final stage of the steam turbine.

4. Need for an economic study - to determine the thermal properties and specifications to design the ideal matrix of solar collectors, which gives the maximum possible economic effectiveness.

The use of combined thermal photoelectric installations to provide consumers in the resort and recreational complex plays a significant role. This is due to the more efficient possibility of using roof areas for the installation of solar thermal photovoltaic installations due to the dense urban development near the place that has a high irradiance. Such solar systems make it possible to reduce the occupied areas due to the complete combined use of thermal and electrical energy from one receiving surface.

Generally, the thermal energy demand will be occupied by more than $50 \%$ of the total energy expenditure. Through the efficient use of the proposed thermal panels, a large amount of environmental heat load will be decreased, and a large amount of electricity used will be saved for the thermal applications

\section{References}

Abd Ali, L. M., Al-Rufaee, F. M., Kuvshinov, V. V. (2020). Study of Hybrid Wind-Solar Systems for the Iraq Energy Complex. Appl. Sol. Energy, 2020, vol. 56, no. 4, pp. 284-290. https://doi.org/10.3103/S0003701X20040027

Abd Ali, L. M., Haider Ahmed, M., Husam Abdulhusein, W. (2019). A Novel Design of 7-Level Diode Clamped Inverter. Journal of Engineering and Applied Sciences, no.14, pp. 3666-3673. https://doi.org/10.36478/jeasci.2019.3666.3673.

Abd Ali, L.M., Issa, H.A. (2018). Hybrid power generation using solar and wind energy, Molod. Uchen., 2018, no.7, pp. 19-26. https://moluch.ru/archive/193/48444.

Abd Ali, L.M., Mohmmed, H.A., Anssari, M.O.H. (2019). Modeling and simulation of tidal energy, J. Eng. Appl. Sci., no. 14, pp. 3698-3706. https://doi.org/10.3923/jeasci.2019.3698.3706

Abdali, L. M., Kuvshinov, V. V., Bekirov, E. A., Al-Rufaee, F. M. (2020). Development of the simulation and control system for an integrated solar energy generation and storage. Construction and industrial safety. Simferopol, Russia, 18, (70), pp. 133-142. doi: https://doi.org/10.37279/2413-1873-2020-18-133-142

Abdali, L.M., Al-Rufaee F. M.Simulation of a model photovoltaic power system to generate electricity. In LinguaNet, 2019, pp. 234-240.

Abdali, L.M., Al-Rufaee, F.M., Yakimovich, B.A., Kuvshinov, V.V. (2020). Optimization of Energy Storage in Hybrid Wind and Photovoltaic Energy Systems. Bulletin of Kalashnikov ISTU, 23(2), pp.100108.doi: 10.22213/2413-1172-2020-2-100-108

Akatov, N., Klačková, I., Mingaleva, Z., Galieva, G. \& Shaidurova, N. (2019). Expert technology for risk management in the implementation of QRM in a high-tech industrial enterprise. Management Systems in Production Engineering 2019, Volume 27, Issue 4, pp. 250-254.

Almsater, S., Saman, W., Frank, B. (2016). Performance enhancement of high temperature latent heat thermal storage systems using heat pipes with and without fins for concentrating solar thermal power plants," Renewable Energy, Elsevier, vol. 89(C), pages 36-50.

Alsharkawi, A., Rossiter, J. (2016). Gain scheduling dual mode mpc for a solar thermal power plant. IFAC-apers OnLine, vol. 49, no. 18, pp.128-133.

Blatnicky, M., Dizo, J., Saga, M., Gerlici, J., Kuba, E. (2020). Design of a Mechanical Part of an Automated Platform for Oblique Manipulation, Applied Sciences-Basel, Vol.10, Issue 23, Article No. 8467, doi: 10.3390/app10238467.

Cernecky, J., Valentov, K., Pivarciov, E., Bozek, P. (2015). Ionization Impact on the Air Cleaning Efficiency in the Interior. Measurement Science Review. Vol. 15, Iss. 4, pp. 156-166, doi: 10.1515/msr-2015-0023.

Cheboxarov, V.V., Yakimovich, B.A., Abd Ali, L.M. (2019). An Offshore Wind-Power-Based Water Desalination Complex as a Response to an Emergency in Water Supply to Northern Crimea. Appl. Sol. Energy, Vol. 55, no. 4, pp. 260-264. https://doi.org/10.3103/S0003701X19040030.

Cheboxarov, V.V., Yakimovich, B.A., Lyamina, N.V. (2019). Some Results of a Study of Wave Energy Converters at Sevastopol State University. Appl. Sol. Energy, vol. 55, no. 4, pp. 256-259. https://doi.org/10.3103/S0003701X19040029.

Conrado, L.S., Rodriguez-Pulido, A. and Calderón, G. (2017). Thermal performance of parabolic trough solar collectors. Renewable and Sustainable Energy Reviews, 67, pp.1345-1359.

Domnina, K. and Pivarčiová, E. (2019). Mathematical model for improvement of concrete quality. Materials Science Forum, 952, pp. 356-362. 
Dodok, T., Čuboňová, N., Kuric, I. Workshop programming as a part of technological preparation of production. In Advances in science and technology-research journal, Vol. 11, Issue 1, pp. 111-116, DOI 10.12913/22998624/66504, Mar. 2017

Figiel, A., Klačková, I. (2020). Safety requirements for mining complexes controlled in automatic mode. In Journal Acta Montanistica Slovaca, Volume 25, 3, ISSN 1335-1788, DOI 10.46544/AMS.v25i3.13.

González-Roubaud, E., Pérez-Osorio, D., Prieto, C. (2017). Review of commercial thermal energy storage in concentrated solar power plants: Steam vs. molten salts. Renewable and Sustainable Energy Reviews, Elsevier, vol. 80(C), pages 133-148.

Guryev, V.V., Yakimovich, B.A., Abd Ali, L (2019). Improvement of Methods for Predicting the Generation Capacity of Solar Power Plants: The Case of the Power Systems in the Republic of Crimea and City of Sevastopol. Appl. Sol. Energy, vol. 55, no. 4, pp. 242-246,https://doi.org/10.3103/S0003701X19040042.

Ivanov, P. (2007). Practical usage of solar energy in Bulgaria for hot water production, Sofia J. Energy, vol. 4, pp.28-37, (Bulgaria).

Janič, P., Jadlovská, S., Zápach, J., Koska, L. (2019). Modeling of underground mining processes in the environment of MATLAB/Simulink. Acta Montanistica Slovaca, 24 (1).

Klačková, I., Zajačko, I., Lenhard, R., Gritsuk, I. and Wiecek, D. (2019). Simulation of wood biomass combustion in hot water boiler, In Conference; Machine Modelling and Simulations 2019, Liptovský Ján, In: IOP Conference Series: Materials Science and Engineering, Volume 776, 24th Slovak-Polish International Scientific Conference on Machine Modelling and Simulations - MMS 2019, 3-6 September 2019, Liptovský Ján, Slovakia

Kuric, I. (2019) New methods and trends in product development and planning. 1st International Conference on Quality and Innovation in Engineering and Management (QIEM). Cluj Napoca, 17.3.-19.3. pp. 453-456, ISBN:978-973-662-614-2

Kuric, I., Cisar, M., Tlach, V., Zajacko, I, Gal, T. and Więcek, D. (2019) Technical Diagnostics at the Department of Automation and Production Systems. Book Series: Advances in Intelligent Systems and Computing, Volume 835, pp. 474-484.

Kuric, I., Gorobchenko, O., Litikova, O., Gritsuk, I., Mateichyk, V., Bulgakov, M. and Klačková,I. (2019). Research of vehicle control informative functioning capacity, In Conference; Machine Modelling and Simulations 2019, Liptovský Ján, In IOP Conference Series: Materials Science and Engineering, Volume 776, 24th Slovak-Polish International Scientific Conference on Machine Modelling and Simulations MMS 2019, 3-6 September 2019, Liptovský Ján, Slovakia.

Kuric, I., Klačková, I., Nikitin, Y.R., Zajačko, I., Císar, M., Tucki, k. (2021). Analysis of diagnostic methods and energy of production systems drives, In Journal; Processes, MDPI, 9, 843, DOI.org/10.3390/pr9050843.

Kuvshinov, V.V., Abd Ali, L.M., Kakushina, E.G. (2019). Studies of the PV Array Characteristics with Changing Array Surface Irradiance. Appl. Sol. Energy, vol. 55, no. 4, pp. 223-228. https://doi.org/10.3103/S0003701X19040054.

Kuvshinov, V.V., Kolomiychenko, V.P., Kakushkina, E.G. (2019). Storage System for Solar Plants. Appl. Sol. Energy, 2019, vol. 55, no. 3, pp. 153-158. https://doi.org/10.3103/S0003701X19030046.

Kuznetsov, N. P., Abd Ali, M. L., Kuvshinov, V. V., Issa, A. H., Mohammed, J. H., Al-bairmani,G. A. (2020). Investigation of the losses of photovoltaic solar systems during operation under partial shading. Journal of Applied Engineering Science, Vol. 18, no. 3, pp. 313 - 320. doi:10.5937/jaes18-24460.

Liaposhchenko, O., Pavlenko, I., Ivanov, V., Demianenko, M., Starynskyi, O., Kuric, I., Khukhryanskiy, O. Improvement of Parameters for the Multi-Functional Oil-Gas Separator of „HEATER-TREATER“ Type. In 2019 IEEE 6th International Conference on Industrial engineering and applications (ICIEA), Waseda Univ, Tokyo, Japan, 12 - 15. apríl 2019, pp. 66-71.

Pástor, M., Živčák, J., Puškár, M., Lengvarský, P., Klačková, I. (2020). Application of Advanced Measuring Methods for Identification of Stresses and Deformations of Automotive Structures. In Applied Sciences Basel 2020, Volume 10, Issue 21, article number 7510, MDPI, ISSN 2076-3417.

Pavlenko, I. Saga, M. Kuric, I. Kotliar, A. Basova, Y. Trojanowska, J. Ivanov, V. (2020). Parameter Identification of Cutting Forces in Crankshaft Grinding Using Artificial Neural Networks. MATERIALS, MDPI, Volume: 13, Issue: 23, Article Number: 5357

Puškár, M., Jahnátek, A., Kuric, I., Kadarová, J., Kopas, M., Soltesova, M. Complex analysis focused on influence of biodiesel and its mixture on regulated and unregulated emissions of motor vehicles with the aim to protect air quality and environment. In Air quality atmosphere and healt, Vol. 12, Issue 7, pp. 855-864, DOI 10.1007/s11869-019-00704-w, 2019.

Repko, A., Saga, M., Sentyakov, B., Sviatskii, V. (2020). Development and Testing of a Block Hydrocyclone, Processes, Vol. 8, Iss. 12, Art. No. 1577, DOI: 10.3390/pr8121577.

Rimar, M., Fedák, M., Váhovský, J., Kulikov, A., Oravec, P., Kulikova, O., Šmajd, M., Káňa, M. (2020). Performance Evaluation of Elimination of Stagnation of Solar Thermal Systems. Processes. Vol. 8, Issue. 5, pp. 1-21 ISSN 2227-9717. 
Škare, M., Tomič, D. \& Stiepanovič, S. (2020). Energy Consumption and Green GDP in Europe: A Panel Cointegration Analysis 2008-2016. Acta Montanistica Slovaca, 25 (1).

Sviatskii, V., Bialy, W., Sentyakov, K. \& Repko, A. (2020). Estimation of Quality Indicators of Ecological Thermoplastic Fiber Materials. Acta Montanistica Slovaca, 25 (1).

Vins, M., Dragoun, J. \& Sirovy, M. (2020). Integration of Battery Energy Storage in Thermal Power Plant. In IECON 2020 The 46th Annual Conference of the IEEE Industrial Electronics Society (pp. 1608-1613). IEEE.

Vologdin, S.V., Yakimovich, B.A. \& Kuvshinov, V.V. (2019). Analysis of Various Energy Supply Scenarios of Crimea with Allowance for Operating Modes of Solar Power Planta. Appl. Sol. Energy, 2019, vol. 55, no. 4, pp. 229-234. https://doi.org/10.3103/S0003701X1904008X.

Wiecek, D., Burduk, A., Kuric, I. The use of ANN in improving efficiency and ensuring the stability of the copper ore mining process. In Acta Montanistica Slovaca, Volume 24, Issue 1, pgs. 1 - 14, 2019. 